\title{
Konstruksi makna pegiat Kelompok Dongeng Bengkimut
}

\author{
Nadia Dwi Putri ${ }^{1}$, Edwin Rizal ${ }^{2}$, Nuning Kurniasih ${ }^{3}$ \\ 1,2,3Program Studi Perpustakaan \& Sains Informasi, Universitas Padjadjaran \\ Jl. Raya Bandung-Sumedang Km. 21, Jatinangor, Sumedang, Jawa Barat, 45363 \\ E-mail: ${ }^{1}$ nadia16014@mail.unpad.ac.id, ${ }^{2} e d w i n . r i z a l @ u n p a d . a c . i d,{ }^{3}$ nuning.kurniasih@unpad.ac.id
}

Received: March 2020; Accepted: May 2020; Published: June 2020

\begin{abstract}
Every activist's introduce stories to children through storytelling. This study discusses the construction of meanings, motives, and experiences of 'Kelompok Dongeng Bengkimut' (Bengkimut Fairytale Group) activists. This research purpose was to discover the meaning, motives, and experiences of storytellers as activists. The research method was qualitative with a phenomenological approach, used were observation, interview, and literature study. Informants were seven active members in the 'Kelompok Dongeng Bengkimut', who had at least four years' experience in joining the group. Study results found that three meanings and two motives could be obtained from the 'Kelompok Dongeng Bengkimut' activists. The meaning possessed is a bearer of happiness, something pleasant, and a messenger. The 'Kelompok Dongeng Bengkimut' owned two motives, namely the motive of reason and purpose. The activist's first motive was a motive for a reason because (s)he was often told tales when (s)he was small, was also comfortable, and was not burdened. Whereas the motive for the purpose was to become an activist, bring up the culture of storytelling, challenge oneself, and introduce books to children. The activist's experience was storytelling in the Children's Ward at Hasan Sadikin Hospital, telling about his work, and storytelling to young and adult listeners. The constraints ever experienced were listeners who did not pay attention to fairy tales, storytelling in groups, and nervousness when storytelling. The conclusion the research that storytelling is meaningful for activist a bearer of happiness, something pleasant, and a messenger, the motive of reason and purpose.
\end{abstract}

Keywords: Kelompok Dongeng Bengkimut; Meaning of activist; Activist motives; Storytelling literacy

\begin{abstract}
ABSTRAK
Setiap pegiat di Kelompok Dongeng Bengkimut mengenalkan cerita pada anak-anak melalui mendongeng. Penelitian ini membahas konstruksi makna, motif, dan pengalaman pegiat Kelompok Dongeng Bengkimut. Tujuan penelitian adalah mengetahui makna, motif, dan pengalaman pendongeng dari pegiat. Metode penelitian yang digunakan dalam penelitian adalah kualitatif melalui pendekatan fenomenologi, menggunakan observasi, wawancara, dan studi kepustakaan. Informan pada penelitian berjumlah tujuh orang anggota aktif pegiat di Kelompok Dongeng Bengkimut yang memiliki pengalaman bergabung minimal empat tahun. Hasil penelitian menemukan adanya tiga makna dan dua motif dari pegiat Kelompok Dongeng Bengkimut. Makna pegiat yaitu pembawa kebahagiaan, sesuatu yang menyenangkan, dan penyampai pesan. Adapun motif menjadi pegiat terbagi menjadi dua yaitu motif alasan dan motif tujuan. Motif alasan yaitu sering didongengkan sejak kecil, nyaman, dan tidak terbebani. Motif tujuan menjadi pegiat yaitu untuk menghidupkan budaya dongeng, menantang diri, dan mengenalkan buku kepada anak-anak. Pengalaman yang pernah dilalui pegiat adalah mendongeng di ruang perawatan anak Rumah Sakit Hasan Sadikin, karyanya didongengkan, mendongeng kepada pendengar remaja dan dewasa, mendongeng di kegiatan besar dan pertama kali mendongeng di Kelompok Dongeng Bengkimut. Kendala yang pernah dilalui pegiat adalah pendengar tidak memperhatikan dongeng, mendongeng secara berkelompok, dan rasa gugup saat mendongeng. Simpulan penelitian bahwa mendongeng bagi pegiat bermakna sebagai pembawa kebahagiaan, sesuatu yang menyenangkan, penyampai pesan, memiliki motif alasan dan tujuan.
\end{abstract}

Kata Kunci: Kelompok Dongeng Bengkimut; Makna pegiat; Motif pegiat; Literasi mendongeng 


\section{PENDAHULUAN}

Komunitas mendongeng di kota besar, khususnya di kota Bandung mengalami perkembangan yang cukup baik. Komunitas mendongeng yang semakin berkembang ini disertai peningkatan kegiatan yang berhubungan dengan mendongeng, seperti seminar, workshop, dan kegiatan mendongeng lainnya untuk anak-anak (Habsari, 2017). Kini beberapa individu atau komunitas sudah giat menumbuhkan dan menghidupkan kembali budaya mendongeng pada anak, salah satunya yaitu Kelompok Dongeng Bengkimut.

Kelompok Dongeng Bengkimut, sebuah komunitas aktif di bidang literasi, yaitu dalam kegiatan mendongeng. Nama "Bengkimut" sendiri merupakan singkatan dari Bengkel Kriya dan Imut. Komunitas ini pun memiliki ciri khas, yakni adanya kegiatan membuat kriya bersama-sama yang berkaitan dengan dongeng yang telah disampaikan pegiat. Kegiatan membuat kriya ini menjadi salah satu kegiatan literasi untuk anak-anak.

Komunitas ini melakukan kegiatan mendongeng di Bandung, di mana anggotanya terdiri dari "Sekelompok individu yang memiliki kesukaan, serta semangat dalam mendongeng dan memahami keasyikan dari kegiatan tersebut bagi segala usia" (Claudine, wawancara, October 24, 2019). Arti dari sekelompok individu ini ialah pegiat dari Kelompok Dongeng Bengkimut.

Para pegiat, awalnya merupakan anggota baru yang belajar mendongeng di Kelompok Dongeng Bengkimut. Sekarang, para pegiat ini secara aktif menebarkan cerita dan mendongeng di Kelompok Dongeng Bengkimut. Para pegiat begitu menghayati cerita yang didongengkan. Hal ini menambah makna dan menjadi refleksi di setiap tindakan dan tingkah laku saat berkegiatan di Kelompok Dongeng Bengkimut.

Para pegiat atau pendongeng terdiri dari pengurus dan anggota aktif Kelompok Dongeng Bengkimut, yang memiliki motif sebagai penggerak kegiatan mendongeng. Berdasarkan temuan penelitian, terdapat dua motif yaitu motif yang mengarah pada maksud, rencana, harapan, dan minat berdirinya Kelompok Dongeng Bengkimut. Pertama, motif yang berorientasi pada masa yang akan datang, "motif untuk atau in-other-to motivates." Kedua, motif yang merujuk pada pengalaman masa lalu, "motif karena atau because motivates", yang tertanam dalam pengetahuan para pegiat Kelompok Dongeng Bengkimut.

Pegiat Kelompok Dongeng Bengkimut memiliki pengalaman mendongeng di komunitas tersebut selama kurang lebih empat tahun. Pengalaman ini memengaruhi setiap aktivitas atau tindakan yang dilakukan para pegiat. Pengalaman merupakan,

“Peristiwa yang tertangkap oleh panca indera dan tersimpan dalam memori. Pengalaman dapat diperoleh, dirasakan saat peristiwa baru saja terjadi atau sudah lama berlangsung. Pengalaman yang terjadi dapat diberikan kepada siapa saja untuk digunakan dan menjadi pedoman serta pembelajaran manusia" (Saparwati, 2012).

Setiap pengalaman yang dimiliki pegiat Kelompok Dongeng Bengkimut akan memengaruhi proses mendongeng. Jadi, para pegiat akan memaknai mendongeng secara berbeda sesuai pengalaman yang dimilikinya. Adapun latar belakang atau ide pendirian Kelompok Dongeng Bengkimut didorong 
atas dasar kesukaan, semangat dalam mendongeng, dan keasyikan mendongeng bagi segala usia. Setiap pegiat, merupakan pendukung Kelompok Dongeng Bengkimut yang memiliki latar belakang profesi dan keseharian yang berbeda-beda. Hal ini contohnya ibu rumah tangga, guru, praktisi pendidikan, pustakawan, penulis, pekerja lepas (freelancer), hingga dosen. Sekelompok orang tersebut membuat Kelompok Dongeng Bengkimut berbekal dari kesukaan, dan semangat yang sama dalam mendongeng. Selain itu, mereka pun ingin menghidupkan kembali tradisi mendongeng di kehidupan sehari-hari.

Kelompok Dongeng Bengkimut tidak memiliki tempat tetap (basecamp) dalam berkegiatan dan selalu berpindah-pindah dari satu tempat ke tempat lainnya (nomaden). Walaupun begitu, Kelompok Dongeng Bengkimut rutin melakukan kegiatan kunjungan mendongeng ke Perpustakaan Emuloka Sekolah Dasar Gagas Ceria dan Pustakalana Children's Library. Kelompok Dongeng Bengkimut mendongeng rutin selama dua kali dalam sebulan di Pustakalana Children's Library, sebagai perpustakaan khusus anak.

Kelompok Dongeng Bengkimut pun mengadakan berbagai kegiatan untuk anak dan dewasa yang erat kaitannya dengan dongeng, seperti dongeng kriya, Klub Otak-Atik, dan workshop. Dongeng Kriya adalah kegiatan yang ditujukan untuk mengajak anak-anak berimajinasi dan mengenal berbagai hal baru melalui dongeng. Lalu, mereka bersama-sama membuat kriya dari cerita yang didengar dari dongeng. Kegiatan ini merupakan salah satu kegiatan pengenalan literasi untuk anak.

Adapun Klub Otak-Atik terdapat dua bagian, Klub Otak-Atik Jelajah dan Klub Otak-Atik Coretan Tutur Rimba. Klub
Otak-Atik Jelajah, merupakan salah satu proses pengenalan sejarah (kawasan dan budaya), atau penggalian potensi pribadi masing-masing anak. Dongeng dalam kegiatan Klub Otak-Atik diposisikan sebagai pengisi bagian pengantar. Di mana anak-anak diajak menyusuri salah satu jalan bersejarah di Bandung, misalnya Jalan Asia Afrika, sambil mengenal lebih dekat kawasan tersebut melalui cerita sejarah, dan keunikan yang melekat. Selain itu, pada kegiatan Klub Otak-Atik Coretan Tutur Rimba, anak-anak dikenalkan pada kawasan Taman Hutan Raya Djuanda. Anak-anak memiliki kesempatan terbuka mengenal hutan kota. Secara tidak langsung, mereka diajak belajar memahami proses pengembangan imajinasi untuk membantu menuangkannya ke dalam bentuk karya dongeng karangan masing-masing.

Selanjutnya, Kelompok Dongeng Bengkimut mengadakan pelatihan (workshop) yang diadakan para pengurus komunitas ini. Pelatihan ini diadakan untuk memotivasi setiap orang agar dapat mendongeng di lingkungan sekitar sehingga kebaikan, keseruan mendongeng dapat ditularkan, dan disebarluaskan. Hal ini sesuai moto Kelompok Dongeng Bengkimut, bahwa semua orang dapat menjadi seorang pendongeng. Pelatihan (workshop) mendongeng diberikan pada kalangan anak-anak dan dewasa. Pelatihan untuk dewasa ini sudah dilakukan sejak 2015, sedangkan pelatihan pada anak-anak diadakan saat Festival Bandung Mendongeng pada 2016.

Ketika kegiatan mendongeng, terdapat seorang fasilitator, yang bertugas membantu pendongeng dalam pelaksanaan kegiatan mendongeng. Fasilitator menyediakan karya seni atau kriya sesuai cerita dari dongeng yang telah 
dibawakan pegiat. Ketika dalam proses pembuatan kriya ini sendiri, anak-anak membutuhkan bantuan orang dewasa untuk mengarahkan dan mengaturnya. Adapun pendengar (audience) kegiatan mendongeng kriya maksimal sepuluh anak. Maka, Kelompok Dongeng Bengkimut membutuhkan dua pegiat dengan pembagian tugas satu orang sebagai pencerita dan yang lainnya sebagai fasilitator. Apabila pendengar berjumlah banyak maka dibutuhkan empat hingga lima orang pegiat.

Mendongeng adalah suatu kegiatan yang sudah dikenal dalam waktu yang lama dan sudah banyak digunakan sebagai kegiatan untuk menghibur. Utomo (2013) mengatakan bahwa dongeng dapat memberikan efek pemuasan terhadap kebutuhan imajinasi dan fantasi anak. Anak akan lebih asyik dalam menyimak dongeng yang berisi nasihat dan ajaran atau didikan. Keinginan dan sikap positif tersebut tentu akan berdampak pada perkembangan pribadi anak usia dini.

Menurut para pegiat Kelompok Dongeng Bengkimut, kegiatan ini merupakan sebuah seni bercerita yang dapat digunakan sebagai media untuk menambahkan dan menanamkan nilainilai pada anak tanpa kesan menggurui. Namun, masyarakat pada zaman ini memiliki anggapan bahwa mendongeng merupakan suatu hal yang konvensional atau kuno karena orang memiliki persepsi bahwa kegiatan ini hanyalah menceritakan sebuah kisah tentang khayalan sebelum anak tidur. Menurut Ardini (2012) menjelaskan bahwa terdapat beberapa orang tua yang enggan mendongeng untuk anak dengan alasan kesibukan. Ayah dan ibu bekerja di luar rumah sehingga mereka tidak lagi memiliki waktu senggang untuk mendongeng bagi anak.

Menurut Mokhtar, Halim, and Kamarulzaman (2011) menjelaskan bahwa mendongeng sebagai alat belajar dapat mendorong siswa mengeksplorasi daya ekspresif, misalnya mengomunikasikan pikiran dan perasaan dengan cara yang jelas. Ternyata, aktivitas ini bermanfaat bagi siswa karena mendongeng memberikan pengalaman seni dan mendukung keterampilan hidup seharihari (Ardini, 2012).

Untuk itu, kegiatan mendongeng dapat dilakukan orang tua, guru, maupun pendongeng (storyteller) sebagai sarana mendidik dan membentuk kepribadian anak. "Storytelling terdiri atas dua kata, yaitu story berarti cerita dan telling berarti penceritaan. Penggabungan dua kata storytelling berarti penceritaan cerita atau menceritakan cerita" (Aliyah, 2011). Selain itu, Suzuki, Feliú-Mójer, Hasson, Yehuda, and Zarate (2018) menjelaskan bahwa mendongeng pun dapat membantu pertumbuhan neuroscientific secara kognitif, dan memberikan nilai pendidikan pada masyarakat umum tentang nilai sains. Sesuai hal ini, mendongeng telah efektif menyampaikan informasi penting kepada para peneliti, orang tua, siswa, dan secara luas membantu meningkatkan praktik sains.

Mendongeng memiliki fungsi dalam memperkenalkan beberapa nilai pada anak. Mendongeng dalam praktiknya terbagi ke dalam dua tahapan, sebagai hiburan, dan sebagai pendidikan karakter.

"Dongeng yang berfungsi sebagai hiburan, dalam penyampaiannya memiliki beragam jenis dongeng, seperti dongeng biasa, fabel, sage, mite atau cerita gaib, dan legenda. Media yang digunakan dapat tokoh anak 
langsung, boneka tangan, wayang, buku seri, maupun alat peraga bebas. Metode pendukung lain seperti penggunaan tepuk, pantomim, maupun sulap edukatif. Berbagai variasi jenis dongeng, media, serta metode pendukung dihadirkan supaya anak merasa tidak bosan dan senang dengan cerita yang disampaikan lewat dongeng" (Nuryanto \& Izzaty, 2016).

Kegiatan cerita memang sudah ada jauh dari sebelum sejarah terbentuk, namun keinginan manusia untuk mendengarkan cerita tidak berubah sampai sekarang. Begitu pun keinginan manusia untuk bercerita. Menurut Sukarno, Permanasari, and Hamidah (2016) menjelaskan bahwa bercerita dapat bermanfaat mendorong anak untuk mencintai bahasa, membantu perkembangan anak, memberikan wadah pada anak untuk belajar mengolah berbagai emosi dan perasaan (sedih, gembira, marah senang, cemas), dan menghidupkan suasana pembelajaran. Maka, bercerita memegang peranan penting dalam mensosialisasikan nilai baru pada anak dan mentransmisikan nilai budaya.

Cerita adalah sebuah perjalanan yang akan menggerakan pendengarnya. Ketika pendengar memutuskan mengikuti perjalanan tersebut, mereka akan merasakan sesuatu yang berbeda, dan hasilnya memersuasi atau bahkan terkadang sebuah tindakan. Seseorang melalui bercerita dapat menyampaikan berbagai macam cerita, mengungkapkan berbagai perasaan sesuai apa yang dialami, dirasakan, dilihat, dibaca, mengungkapkan kemauan, dan keinginan dalam membagikan pengalaman yang diperolehnya.
Manusia pun melalui cerita mampu memahami dunia dan apa yang terjadi pada kehidupannya. Serta manusia mengetahui jati diri dan pengakuan diri sebagai individu bagian dari suatu komunitas. Pada kenyataannya, mendongeng mampu memengaruhi pemikiran seseorang dan bahkan dapat memengaruhi pengetahuan melalui metode pembelajaran yang dilakukan secara formal atau non formal.

Setiap daerah atau negara, memiliki cerita yang berbeda sesuai budaya dan ciri khas cerita yang disampaikan dan ditangkap. Budaya mendongeng (strorytelling) yang diceritakan pada anak di Indonesia mengisahkan tentang cerita rakyat pada zaman dahulu atau kisah asal mula suatu daerah. Penerapan mendongeng di negara barat pun lebih menceritakan pengetahuan dalam pembentukan karakter masyarakat yang melek akan informasi. Maka, tanpa disadari, mendongeng memiliki banyak sekali manfaat apabila orang tua atau dewasa terus mendongeng pada anak. Salah satunya diungkapkan Habsari (2017), bahwa mendongeng memiliki manfaat dalam mengajarkan budi pekerti pada anak, membiasakan budaya membaca, dan mengembangkan imajinasi.

Pendongeng atau pencerita dalam kegiatan mendongeng memiliki peran yang penting. Pendongeng biasanya dapat memahami karakter pendengar, menirukan suara, pandai mengatur nada dan intonasi, serta terampil menggunakan alat bantu peraga. Oleh sebab itu, pendongeng harus memiliki kemampuan, dan keterampilan yang baik dalam public speaking.

Pendongeng adalah seorang komunikator yang aktif menyampaikan pesan berupa cerita kepada komunikan, 
yakni anak-anak sebagai pendengar (audience). Pendongeng pada Kelompok Dongeng Bengkimut menjadi penentu kesuksesan kegiatan mendongeng. Pendongeng harus memiliki keterampilan, dan mampu mementaskan sebuah cerita melalui gaya, intonasi, dan alat bantu yang dapat menarik minat para pendengar. Untuk itu, mendongeng dapat dikatakan berhasil, jika sasaran atau pendengar mampu menangkap jalan cerita, dan merasa terhibur dari cerita yang disampaikan pendongeng. Selain itu, pendengar pun mendapatkan pesan moral atas cerita yang disampaikan dari penyaji.

Pendongeng harus menyampaikan isi cerita dengan baik agar cerita yang disampaikan menarik. Pendongeng dan isi cerita merupakan kesatuan utuh dari proses mendongeng. Spaulding (2011) menceritakan pengalamannya ketika berbincang dengan guru tai chi, dan guru tersebut menyatakan bahwa energi dalam penyampaian cerita kepada pendengar sama besar dengan tenaga yang digunakan pada tai chi. Sesuai hal tersebut, dapat dilihat bahwa mendongeng terlihat seperti kegiatan yang sederhana, tetapi sesungguhnya banyak aspek yang harus dilakukan ketika melakukannya. Aspek ini harus menghasilkan kegiatan bercerita yang menyenangkan. Maka, pendongeng harus mampu mengelola dan menghasilkan kegiatan mendongeng yang menyenangkan.

Spaulding (2011) menambahkan bahwa cerita sudah memiliki nilai dan pesan tersendiri di dalamnya tanpa pendongeng sebagai perantara cerita dengan pendengar atau pembaca. Peran pendongeng sebagai penyampai isi cerita merupakan nilai tambah. Apabila pendongeng melakukan perannya dengan baik dan maksimal, maka akan menambah nilai dari cerita tersebut. Untuk itu, peran pendongeng dapat menentukan keefektifan pesan yang diterima dan masuk ke dalam diri pendengar. Pendongeng harus berada di level yang sama dengan energi dari cerita itu sendiri.

Mendongeng bukan hanya menimbulkan kesan sebagai hiburan semata, namun tanpa disadari pesan yang disampaikan pun memengaruhi pendengar seumur hidup. Energi dalam kegiatan mendongeng bukan sekedar energi yang pindah dari satu orang ke orang yang lainnya secara fisik, tetapi lebih dari itu. Spaulding (2011) kembali menuturkan kalau energi yang ditimbulkan dari mendongeng adalah pemikiran yang menarik dan dapat melekat di pikiran seseorang tanpa disadari.

Sesuai pemaparan di atas, mendongeng memiliki beberapa manfaat bagi para pendengar, khususnya anakanak. Kelompok Dongeng Bengkimut masih bergerak aktif melestarikan kegiatan mendongeng dengan menggunakan teknologi informasi dan komunikasi yang sudah maju. Hal ini menjadikan topik ini menarik dianalisis ke dalam sebuah penelitian. Berdasarkan penelusuran yang dilakukan peneliti, penelitian yang secara khusus membahas tentang komunitas yang bergerak di bidang mendongeng belum banyak diteliti. Untuk itu, peneliti tertarik melakukan penelitian mengenai konstruksi makna pegiat Kelompok Dongeng Bengkimut.

Kelompok Dongeng Bengkimut menyadari bahwa mendongeng atau bercerita merupakan kegiatan yang sangat bermanfaat, dan mampu menghasilkan dampak positif bagi para pendengar, walaupun masyarakat masih berpandangan mendongeng sebagai 
sesuatu yang kuno. Berdasarkan pemaparan latar belakang di atas, penelitian ini bertujuan mengetahui makna, motif, dan pengalaman pendongeng sebagai pegiat di Kelompok Dongeng Bengkimut.

\section{METODE PENELITIAN}

Peneliti dalam penelitian ini menggunakan pendekatan kualitatif untuk menjelaskan bagaimana konstruksi makna setiap pegiat Kelompok Dongeng Bengkimut. Peneliti pun ingin mengetahui bagaimana motif dan pengalaman para pegiat Kelompok Dongeng Bengkimut. Adapun metode penelitian yang digunakan yaitu metode fenomenologi.

"Fenomenologi ialah ilmu pengetahuan (logos) tentang apa yang tampak (phenomena). Fenomenologi dengan demikian, merupakan ilmu yang mempelajari, atau apa yang menampakkan diri fenomenon, sehingga setiap penelitian atau setiap karya yang membahas cara penampakkan dari apa saja, sudah merupakan fenomenologi. Penelitian kualitatif dalam payung paradigma interpretif ini dalam pengertian sederhana, sesungguhnya kita pada waktu-waktu tertentu mempraktikkan fenomenologi dalam keseharian hidup kita. Kita mengamati fenomena, kemudian kita membuka diri, kita membiarkan fenomena itu tampak pada kita, lalu kita memahaminya sampai pada akhirnya kita mampu memahaminya dalam perspektif fenomena itu sendiri, bagaimana ia bercerita dan menunjukkannya kepada kita" (Nuryana, Pawito, \& Utari, 2019).

Subjek dalam penelitian kualitatif biasa disebut informan. Subjek penelitian dalam sebuah penelitian mempunyai peran yang strategis karena menjadi sumber data variabel yang diamati. Adapun peneliti menggunakan teknik Purposive sampling sebagai teknik pemilihan informan atau teknik sampling dalam menentukan subjek penelitian. "Purposive sampling adalah teknik pengambilan sampel sumber data dengan pertimbangan tertentu" (Sugiyono, 2016). Peneliti dalam menentukan informan menggunakan kriteria seseorang yang mengalami situasi atau kejadian yang berkaitan dengan topik mendongeng pada Kelompok Dongeng Bengkimut. Informan mampu menggambarkan kembali fenomena kegiatan mendongeng yang telah dialaminya. Informan merupakan anggota aktif Kelompok Dongeng Bengkimut, dan memiliki pengalaman sebagai pegiat di Kelompok Dongeng Bengkimut minimal empat tahun. Berdasarkan kriteria informan di atas, subjek penelitian yang dipilih adalah pegiat Kelompok Dongeng Bengkimut sebagai pendongeng (storyteller).

Menurut Sugiyono (2016), objek penelitian merupakan suatu atribut atau sifat atau nilai dari orang, objek atau kegiatan yang mempunyai variabel tertentu yang ditetapkan untuk dipelajari dan ditarik kesimpulan. Sesuai pernyataan ini dapat disimpulkan bahwa objek penelitian adalah tujuan atau sasaran yang ingin dicapai penulis untuk mendapatkan data yang digunakan berupa makna, motif dan pengalaman dari pegiat Kelompok Dongeng Bengkimut.

Maka penulis menggunakan dua sumber data, yaitu sumber data primer dan sumber data sekunder. Data primer yaitu data yang dikumpulkan langsung penulis dari sumber utama dari pegiat Kelompok Dongeng Bengkimut. Adapun 
data sekunder yaitu data yang langsung dikumpulkan penulis sebagai penunjang dari sumber pertama, misalnya data yang didapatkan dari perpustakaan atau data yang berkaitan dengan penelitian ini.

Teknik pengumpulan data dalam penelitian ini melalui observasi, wawancara, dan studi kepustakaan. Informan pada penelitian berjumlah tujuh orang anggota aktif pegiat di Kelompok Dongeng Bengkimut yang memiliki pengalaman bergabung minimal empat tahun.

\section{HASIL DAN PEMBAHASAN}

Kelompok Dongeng Bengkimut yang dibentuk pada tanggal 25 Oktober 2014. Komunitas ini memiliki delapan orang anggota aktif sebagai pendongeng dan pegiat. Sesuai hasil wawancara yang dilakukan peneliti kepada para pegiat Kelompok Dongeng Bengkimut, didapatkan makna, motif, dan pengalaman para pegiat yang terdapat pada tabel 1.

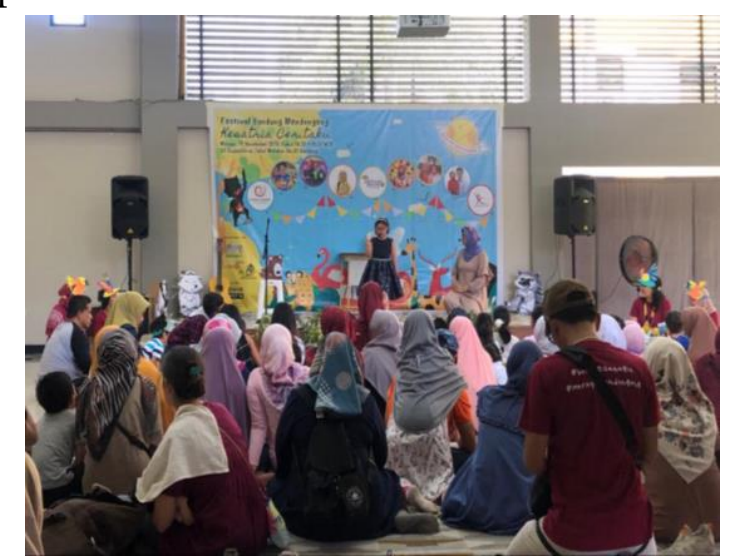

Gambar 1. Festival Bandung Mendongeng 2019 oleh Kelompok Dongeng Bengkimut Sumber: Dokumentasi penelitian, 2019

Selama berkegiatan dalam Kelompok Dongeng Bengkimut empat tahun lamanya sejak tahun 2014 hingga saat ini, mereka memiliki makna terhadap dirinya sendiri sebagai pegiat Kelompok Dongeng Bengkimut. Hal ini dikatakan bahwa,
“Konstruksi sosial tidak terbangun tanpa makna, karena terdapat kepentingan di dalamnya. Realitas sosial dapat terbentuk karena individu di dalamnya saling melakukan interaksi, saling mengkonstruksi dan merekonstruksi dalam realitas tersebut. Konstruksi sosial atas realitas lebih tentang bagaimana individu berkomunikasi dan berinteraksi akan cenderung untuk mempertanyakan mengenai aktivitas dirinya dan juga mempelajari aktivitas individu lainnya sehingga memiliki pemahaman yang sama sehingga tercipta objektivitas baru" (Istiani, 2015).

Sesuai rujukan ini dikatakan bahwa realitas sosial dibentuk dari interaksi sosial. Individu saling merekonstruksi realitas sosial hingga mendapatkan makna atas interaksi tersebut. Pada pegiat Kelompok Dongeng Bengkimut pun, makna mendongeng muncul dari interaksi antar pegiat dan pendengar. Para pegiat Kelompok Dongeng Bengkimut saling melakukan interaksi dan saling melakukan konstruksi satu sama lain. Konstruksi sosial yang dimaksud adalah bagaimana para pegiat Kelompok Dongeng Bengkimut melakuka interaksi kemudian mempertanyakan aktivitas mereka selama berkegiatan di Kelompok Dongeng Bengkimut. Selain itu, mereka mempelajari aktivitas para pegiat lainnya sehingga memiliki pemahaman yang sama dan akhirnya tercipta makna dirinya sebagai pegiat Kelompok Dongeng Bengkimut.

Berdasarkan hasil wawancara kepada tujuh orang informan, peneliti memperoleh tiga makna dari pegiat Kelompok Dongeng Bengkimut, di 
antaranya makna pembawa kebahagiaan, penyampai pesan, dan sesuatu yang menyenangkan. Makna pertama, para pegiat Kelompok Dongeng Bengkimut sebagai pembawa kebahagiaan. Para pegiat Kelompok Dongeng Bengkimut mendongeng untuk membuat pendengar menjadi senang dan bahagia, yang awalnya sedih, stres, dan kondisi pikiran yang tidak baik. Hal ini terlihat dari ekspresi pendengar yang tersenyum dan tertawa ketika mendengarkan dongeng yang dibawakan pegiat Kelompok Dongeng Bengkimut. Selain itu, hal ini terlihat dari pancaran mata para pendengar, khususnya anak-anak yang berbinar dan tidak jarang mereka tertawa menandakan bahwa mereka merasa bahagia. Sesuai reaksi yang didapatkan dari pendengar ketika mendengarkan dongeng, para pegiat memaknai dirinya sebagai pembawa kebahagiaan. Para pegiat juga memiliki tujuan untuk membuat pendengarnya senang dan bahagia sesuai segala aktivitas serta kegiatan yang dilakukan Kelompok Dongeng Bengkimut.

Makna yang kedua, yaitu sebagai penyampai pesan. Para pegiat Kelompok Dongeng Bengkimut menyampaikan dongeng pada pendengarnya, yang berisi pesan yang jelas atau (eksplisit) dan pesan yang tersembunyi (implisit). Pendengar menerima pesan dari isi cerita secara disadari atau tidak disadari.

Pegiat berusaha mengemas pesan sedemikian rupa sehingga dapat diterima pendengar. Pendengar yang memiliki pengetahuan luas maka pesan cerita dikemas secara kompleks, sedangkan pendengar yang memiliki pengetahuan tidak terlalu luas, seperti anak-anak maka pesan dikemas sederhana.

$\begin{array}{lccr}\quad \text { Pegiat } & \text { dalam } & \text { mengemas } & \text { cerita } \\ \text { dongeng } & \text { harus } & \text { dilakukan } & \text { secara } \\ \text { maksimal } & \text { agar } & \text { pendengar } & \text { dapat }\end{array}$
menerima dan memahami pesan sebaik mungkin. Adapun pesan yang disampaikan pegiat, berupa informasi, pelajaran, dan pengalaman hidup pegiat. Pada umumnya, target mendongeng yaitu anak-anak, sebagai generasi selanjutnya yang harus diberikan masukan yang baik. Namun, dongeng pun dapat diberikan kepada orang dewasa yang berfungsi untuk membangun dan mengingatkan.

Makna yang ketiga, yaitu sesuatu yang menyenangkan. Setiap aktivitas yang dilakukan pegiat Kelompok Dongeng Bengkimut sangat menyenangkan. Meskipun kegiatan yang dilakukan dalam Kelompok Dongeng Bengkimut itu sulit, namun proses kegiatan tersebut tetap menyenangkan. Pegiat Kelompok Dongeng Bengkimut kadangkala menemukan kesulitan ketika mendongeng, tetapi mendongeng menjadi sesuatu yang menyenangkan. Seluruh proses kegiatan mendongeng yang dimulai dari persiapan, pelaksanaan, dan evaluasi menjadi suatu hal yang sangat menyenangkan.

Para pegiat di setiap proses yang dilalui sangat menikmati semuanya, seperti ketika mempersiapkan cerita yang akan disampaikan, mempersiapkan alat bantu berupa properti, berlatih mendongeng, penyampaian dongeng, dan respon balik pendengar yang membuat para pegiat merasa senang. Pada intinya, setiap kegiatan dan aktivitas di Kelompok Dongeng Bengkimut sangat menyenangkan sehingga para pegiat memaknai mendongeng sebagai sesuatu yang menyenangkan.

Para pegiat Kelompok Dongeng Bengkimut mendongeng pada pendengar 
selalu didasari motif.

"Istilah motivasi berasal dari kata motif yang dapat diartikan sebagai kekuatan yang terdapat dalam diri individu, yang menyebabkan individu tersebut bertindak atau berbuat. Motif tidak dapat diamati secara langsung, tetapi dapat dilakukan interpretasi dalam tingkah laku berupa rangsangan, dorongan, atau pembangkit tentang munculnya suatu tingkah laku tertentu" (Moncot, 2019).

Jika dikaitkan dalam penelitian ini, motif para pegiat Kelompok Dongeng Bengkimut tidak dapat diamati secara langsung. Hal ini dapat ditafsirkan dalam tingkah laku berupa rangsangan, dorongan, atau sesuatu yang membangkitkan pegiat menjadi anggota aktif dan berkegiatan di Kelompok Dongeng Bengkimut sejak empat tahun yang lalu. Motif sendiri, terdiri dari motif tujuan (in order to motive) dan motif alasan (because motive). Para pegiat Kelompok Dongeng Bengkimut memiliki motif sendiri ketika bergabung dan menjadi pegiat, yakni motif yang mengarah pada tujuan, rencana, harapan, minat, dan sebagainya dari berdirinya Kelompok Dongeng Bengkimut. Motif tersebut berorientasi pada masa yang akan datang, motif untuk (in-other-to motivates).

Motif kedua dari dibentuknya Kelompok Dongeng Bengkimut yaitu merujuk pada pengalaman masa lalu dan tertanam dalam pengetahuan para pegiat Kelompok Dongeng Bengkimut. Motif ini berorientasi pada masa lalu, motif karena (because motivates). Sejumlah individu bergabung dan menjadi pegiat Kelompok Dongeng Bengkimut memiliki motif alasan karena sering didongengkan sejak kecil, merasa nyaman, dan tidak terbebani. Motif alasan pertama yaitu, sering didongengkan sejak kecil oleh orang tua dan kakek neneknya. Para pegiat Kelompok Dongeng Bengkimut sudah ditanamkan budaya mendongeng sejak kecil oleh orang tua dan kakek neneknya. Budaya mendongeng yang ditanamkan keluarga sejak kecil membuat para pegiat Kelompok Dongeng Bengkimut menjadi senang dan gemar membaca mulai dari membaca majalah, cerita, dan sebagainya.

Selain itu, pegiat dikenalkan mendongeng oleh kakek dan neneknya yang terbiasa menonton pertunjukkan wayang. Kegiatan ini merupakan salah satu kegiatan dari seni bercerita. Pegiat menyebutnya sebagai kegiatan atau aktivitas bertutur cerita. Maka, pegiat yang terbiasa mendengarkan cerita sejak kecil, akhirnya mereka menyukai kegiatan yang berhubungan dengan cerita. Mereka pun terjun dalam dunia mendongeng dan menjadi pegiat Kelompok Dongeng Bengkimut hingga saat ini.

Motif alasan kedua, pegiat merasa nyaman dan tidak terbebani. Kelompok Dongeng Bengkimut tidak membebani para anggota untuk memiliki kemampuan atau keahlian tertentu. Komunitas ini tidak mengharuskan pegiatnya menggunakan properti atau aturan lain. Jadi, para pegiat Kelompok Dongeng Bengkimut dapat mengekspresikan cerita sesuai kemampuan dan daya tarik masing-masing.

$$
\text { Pegiat Kelompok Dongeng }
$$

Bengkimut dibebaskan dalam mendongeng. Mereka dapat bermain ekspresi dan bahasa tubuh sedemikian rupa, tanpa terpaku penggunaan properti. Hal ini menjadi alasan pegiat Kelompok Dongeng Bengkimut bergabung dan berkegiatan selama empat tahun sejak 
2014 hingga saat ini. Mereka merasa tidak terpaksa dalam membawakan dongeng. Pada intinya, motif alasan pegiat Kelompok Dongeng Bengkimut yaitu perasaan nyaman dan tidak terbebani.

Adapun motif tujuan dari para pegiat di antaranya menghidupkan budaya dongeng, menantang diri, dan mengenalkan buku kepada anak-anak. Motif tujuan pertama, pegiat ingin menghidupkan kembali budaya dongeng. Para pegiat menyadari bahwa budaya mendongeng di masyarakat mulai pudar karena masyarakat terlena atas perkembangan teknologi. Maka, tujuan berdirinya Kelompok Dongeng Bengkimut yaitu menghidupkan kembali budaya mendongeng di tengah masyarakat.

Sesuai motif tujuan ini, Kelompok Dongeng Bengkimut telah membuat pelbagai kegiatan yang berkaitan dengan mendongeng, misalnya kunjungan mendongeng, dongeng kriya, festival dongeng, workshop dongeng untuk orang tua, guru, mahasiswa, dan masyarakat umum. Kegiatan pada Kelompok Dongeng Bengkimut ini bertujuan mengembalikan dan menghidupkan budaya mendongeng melalui segala esensinya di tengah masyarakat, khususnya lingkup rumah dan sekolah.

Adapun sasaran Kelompok Dongeng Bengkimut adalah semua kalangan, utamanya anak-anak dan orang tua. Berdasarkan segala kegiatan yang dilakukan pegiat Kelompok Dongeng Bengkimut, diharapkan dapat mengembalikan dan menghidupkan kembali dongeng di masyarakat. Hal ini sesuai motif tujuan pegiat Kelompok Dongeng Bengkimut.

Motif tujuan kedua, menantang diri dalam mengalahkan ketakutan saat mendongeng, khususnya pada anak-anak yang masih berumur di bawah lima tahun (balita). Anak balita masih sulit dikendalikan dan dapat memberikan reaksi yang tidak terduga. Ketika pegiat Kelompok Dongeng Bengkimut membawakan dongeng kepada anak balita, terkadang mereka berlarian dan tidak mendengarkan dongeng yang diberikan. Ketika pegiat Kelompok Dongeng Bengkimut membawakan dongeng kepada anak-anak, mereka membuktikan dapat menantang diri dalam melawan ketakutan menghadapi anak balita. Arti menantang diri ialah para pegiat harus tampil mendongeng di depan banyak orang karena mendongeng adalah kegiatan bercerita yang disajikan kepada beberapa orang.

Motif tujuan ketiga, pegiat Kelompok Dongeng Bengkimut mengenalkan buku kepada anak-anak. Beberapa individu tersebut bergabung dan menjadi pegiat Kelompok Dongeng Bengkimut adalah ingin mengenalkan buku sebagai sesuatu yang menyenangkan dan menarik kepada anak-anak. Maka, pegiat memilih metode mendongeng dalam merealisasikan pengenalan bahwa buku adalah sesuatu yang menyenangkan kepada anak-anak. Pada umumnya, mendongeng pada kelompok kecil menggunakan buku dan diharapkan dapat sedikit demi sedikit mengenalkan buku pada anak-anak. Hal ini untuk membuat anak-anak terbiasa dan menyukai kegiatan membaca buku.

Pegiat Kelompok Dongeng Bengkimut setelah aktif mendongeng sejak tahun 2014 hingga saat ini, pasti terdapat pengalaman yang berkesan, tidak terlupakan, dan pengalaman yang menjadi kendala. Pengalaman adalah kejadian atau peristiwa yang telah dialami seseorang. Setiap peristiwa yang dilewati 
pasti akan menjadi pengalaman yang selalu diingat.

Pengalaman pertama, pegiat Kelompok Dongeng Bengkimut memiliki pengalaman berkesan selama berkegiatan yakni mendongeng untuk anak penderita kanker di Rumah Sakit Hasan Sadikin (RSHS). Pegiat Kelompok Dongeng Bengkimut bersama komunitas dan kelompok dongeng lain pernah mengisi dongeng di RSHS. Mereka menuju ruang perawatan anak untuk mendongeng menggunakan media buku dan properti lainnya, contohnya cerita seekor anak monyet yang menyukai satu baju padahal baju tersebut sudah sangat kotor.

Pengalaman mendongeng bagi anak penderita kanker di RSHS menjadi berkesan dan tidak terlupakan oleh pegiat Kelompok Dongeng Bengkimut karena kondisi pendengar yang kondisinya berbeda. Pegiat ketika melihat ekspresi anak-anak tersenyum, menjadi sesuatu yang tidak bisa dibayar oleh uang dan tidak dapat diganti apapun.

Pengalaman yang kedua yaitu ketika karyanya didongengkan. Beberapa pegiat Kelompok Dongeng Bengkimut memiliki profesi sebagai penulis dan menulis cerita anak atau cerita pendek. Kemudian mereka mendongengkan isi cerita atau didongengkan oleh pegiat lainnya. Bagi pegiat yang memiliki profesi sebagai penulis, hal ini menjadi suatu kebanggaan dan kebahagiaan yang lengkap karena karya tulisannya diapresiasi dan ditanggapi dengan baik.

Pengalaman ketiga, mendongeng kepada pendengar remaja dan dewasa. Biasanya, Kelompok Dongeng Bengkimut mendongeng melalui kunjungan dongeng dan dongeng kriya yang target pendengarnya anak-anak. Namun, pada beberapa kesempatan Kelompok Dongeng
Bengkimut pernah diminta mendongeng dalam beberapa acara atau kegiatan tertentu yang ternyata pendengarnya remaja dan dewasa pada acara Gerakan Literasi Kota dan Festival Bambu. Kesempatan ini menjadi salah satu pengalaman yang berkesan bagi pegiat. Pada awalnya pegiat mendongeng pada pendengar remaja dan dewasa akan sulit tetapi ternyata mereka mendapatkan respon yang baik. Pendengar remaja dan dewasa menikmati dongeng yang disajikan pegiat Kelompok Dongeng Bengkimut.

Pengalaman keempat, yaitu mendongeng di acara yang besar. Pegiat Kelompok Dongeng Bengkimut telah mendongeng dalam beberapa acara besar. Acara Festival Anak Bertanya (FAB), adalah acara besar yang dihadiri beribu peserta pada 12 Mei 2018 di Sasana Budaya Ganesha (Sabuga) Bandung. Selain itu, Acara Festival Dongeng Internasional Indonesia (FDII) yang telah diadakan beberapa kali, misalnya pada 56 November 2016 dan 2 November 2019 di Museum Nasional Republik Indonesia, dan 4-5 November 2017 di Perpustakaan Nasional Republik Indonesia. Di mana pengunjung sebagian besar dalam acara ini ialah anak, remaja, dan dewasa. Hal ini membuat pegiat mendongeng pada pendengar remaja dan dewasa karena pengunjung ini biasanya berkunjung mengikuti dongeng kriya yang pendengarnya anak-anak.

Pada acara besar di atas, Kelompok Dongeng Bengkimut membawakan dongeng untuk ratusan pendengar. Pegiat mendongeng dalam acara nasional dan internasional, yang dihadiri pendongeng profesional dari dalam dan luar negeri. Hal ini menjadi suatu kebanggaan bagi Kelompok Dongeng Bengkimut dan para 
pegiatnya. Pegiat harus menampilkan dongeng yang terbaik dan melakukan persiapan yang matang karena dihadiri ribuan orang. Persiapan yang dilakukan dimulai dari properti atau alat bantu lainnya, cerita yang akan dibawakan, dan kesiapan diri para pegiat. Oleh sebab itu, para pegiat Kelompok Dongeng Bengkimut menyiapkan diri dengan latihan secara maksimal agar dapat tampil membawakan dongeng dengan baik dan menghibur para pendengar.

Pengalaman kelima, yaitu pengalaman pertama kali mendongeng saat bergabung di Kelompok Dongeng Bengkimut. Bagi pegiat, momen pertama kali mendongeng di Kelompok Dongeng Bengkimut adalah peristiwa yang berkesan, meninggalkan kesan tersendiri. Ketika pertama kali menjadi pegiat, mereka harus praktik mendongeng pada anak-anak di Perpustakaan Umum Elmuloka. Tepatnya pada 2014, menjadi awal terbentuknya Kelompok Dongeng Bengkimut, di mana pegiat harus mendongeng secara bergantian.

Pada saat itu, pegiat Kelompok Dongeng Bengkimut mendongeng untuk anak-anak yang sudah selesai sekolah dan menunggu dijemput orang tua di taman kanak-kanak (playgroup) serta Sekolah Dasar Gagas Ceria. Setiap pegiat memiliki gaya masing-masing saat pertama kali mendongeng, misalnya ada pegiat yang menggunakan alat musik, menggunakan properti sebagai alat bantu, dan lain sebagainya.

Adapun pengalaman yang menjadi kendala bagi pegiat Kelompok Dongeng Bengkimut, yaitu ketika pendengar tidak memperhatikan dongeng, mendongeng secara berkelompok, dan perasaan gugup ketika mendongeng. Pegiat Kelompok Dongeng Bengkimut mengalami kendala ketika pendengar tidak memperhatikan dongeng yang sedang dibawakan pegiat, mendongeng secara berkelompok, dan munculnya perasaan gugup saat mendongeng.

Kendala pertama adalah ketika pendengar tidak memperhatikan dongeng yang sedang dibawakan pegiat. Hal ini menjadi tantangan besar bagi pegiat untuk mengembalikan perhatian pendengar yang sudah tidak fokus mendengarkan dongeng. Walaupun pendengar sudah mulai mendengarkan namun mereka belum tentu fokus dan cermat terhadap isi cerita. Maka, pegiat Kelompok Dongeng Bengkimut akan mengabaikan hal ini dan fokus mendongeng kepada pendengar yang serius mendengarkan dongeng. Apabila hal ini tidak dilakukan, maka pegiat Kelompok Dongeng Bengkimut akan tidak konsentrasi dan tidak fokus pada cerita yang disampaikan. Selain itu, ada pula ada kejadian yang tidak menyenangkan ketika pendengar anakanak tidak memperhatikan dongeng. Anak-anak malah berlarian dan bermain lempar sepatu. Hal ini membuat pegiat hilang konsentrasi dan pikiran teralihkan karena gangguan dari pendengar.

Kendala kedua, yaitu mendongeng secara berkelompok. Kelompok Dongeng Bengkimut mendongeng secara berkelompok dilakukan pada Festival Dongeng Internasional Indonesia di Jakarta. Kelompok Dongeng Bengkimut telah berlatih dan melakukan persiapan seperti membuat naskah dongeng agar alur cerita yang disampaikan tersusun. Namun kenyataannya, mendongeng secara kelompok bukan hal yang mudah. Ketika salah satu pegiat Kelompok Dongeng Bengkimut melakukan kesalahan, maka pegiat lain 
menggunakan isyarat memberitahukan kesalahannya dan menghentikan gilirannya mendongeng, agar alur dongeng dapat kembali seperti persiapan sebelumnya. Namun memberikan isyarat kepada pegiat Kelompok Dongeng Bengkimut yang melakukan kesalahan tidaklah mudah.

Kendala ketiga, perasaan gugup ketika mendongeng. Hal ini terjadi ketika mereka mendongeng dalam jumlah pendengar yang tidak sedikit. Terkadang, para pegiat Kelompok Dongeng Bengkimut terlalu mengkhawatirkan kepada pendengar yang tidak serius memperhatikan dongeng, misalnya pendengar di bagian belakang. Para pegiat Kelompok Dongeng Bengkimut terkadang terlalu memikirkan bagaimana pembawaan saat mendongeng, seperti suara, ekspresi, dan sebagainya. Pegiat yang terlalu banyak memikirkan hal ini dapat menimbulkan perasaan gugup dan tidak fokus ketika mendongeng. Oleh sebab itu, para pegiat Kelompok Dongeng Bengkimut mengatasinya dengan melakukan persiapan yang matang agar bisa menampilkan yang terbaik saat mendongeng. Pegiat Kelompok Dongeng Bengkimut memiliki persiapan yang berbeda-beda, contohnya ada pegiat yang menghafalkan alur cerita, menyiapkan properti membaca buku, dan lain sebagainya. Pegiat melakukan persiapan yang matang sebelum mendongeng agar memiliki rasa percaya diri ketika mendongeng dan dapat menekan rasa gugup yang muncul.

\section{SIMPULAN}

Berdasarkan hasil penelitian, pegiat Kelompok Dongeng Bengkimut yang mendongeng memiliki makna sebagai pembawa kebahagiaan, sesuatu yang menyenangkan, dan penyampai pesan. Pegiat berharap pendengar dapat menjadi bahagia melalui dongeng yang dibawakan. Pegiat pun memaknai setiap aktivitas di Kelompok Dongeng Bengkimut menjadi sesuatu yang menyenangkan, dan dapat menyampaikan pesan cerita pada pendengar. Pegiat Kelompok Dongeng Bengkimut memiliki dua motif utama, motif alasan (because motives) dan motif tujuan (in order to motives). Pegiat Kelompok Dongeng Bengkimut dalam motif alasan yaitu sering didongengkan sejak kecil, nyaman, dan tidak terbebani. Motif tujuan menjadi pegiat yaitu untuk menghidupkan budaya dongeng, menantang diri, dan mengenalkan buku kepada anak-anak. Pengalaman yang pernah dilalui pegiat adalah mendongeng di ruang perawatan anak Rumah Sakit Hasan Sadikin, karyanya didongengkan, mendongeng kepada pendengar remaja dan dewasa, mendongeng di kegiatan besar dan pertama kali mendongeng di Kelompok Dongeng Bengkimut. Kendala yang pernah dilalui pegiat adalah pendengar tidak memperhatikan dongeng, mendongeng secara berkelompok, dan rasa gugup saat mendongeng. Peneliti memiliki rencana mengembangkan penelitian lebih lanjut mengenai kemampuan dan keterampilan pegiat Kelompok Dongeng Bengkimut dalam mendongeng dan mengenai pengaruh mendongeng terhadap pendengar setelah mendengarkan dongeng yang disampaikan pegiat.

\section{DAFTAR PUSTAKA}

Aliyah, S. (2011). Pengaruh metode storytelling dengan media panggung boneka terhadap peningkatan kemampuan menyimak dan berbicara anak usia dini: Studi eksperimen quasi di TK Negeri 
Pembina Kabupaten Majalengka (Tesis) [Universitas Pendidikan Indonesia, Bandung].

http:/ / repository.upi.edu/8747/

Ardini, P. P. (2012). Pengaruh dongeng dan komunikasi terhadap perkembangan moral anak usia 7-8 tahun. Jurnal Pendidikan Anak, 1(1), 4458.

https:/ / doi.org/10.21831/jpa.v1i1.290 5

Habsari, Z. (2017). Dongeng sebagai pembentuk karakter anak. BIBLIOTIKA: Jurnal Kajian Perpustakaan Dan Informasi, 1(1), 21-29. https:/ / doi.org/10.17977/um008v1i12 017p021

Istiani, A. N. (2015). Konstruksi makna hijab fashion bagi moslem fashion blogger. Jurnal Kajian Komunikasi, 3(1), 48-55.

https:/ / doi.org/10.24198/jkk.v3i1.739 3

Mokhtar, N. H., Halim, M. F. A., \& Kamarulzaman, S. Z. S. (2011). The effectiveness of storytelling in enhancing communicative. ProcediaSocial and Behavioral Sciences, 18(1), 163-169.

https:/ / doi.org/10.1016/j.sbspro.2011 .05 .024

Nuryana, A., Pawito, \& Utari, P. (2019). Pengantar metode penelitian kepada suatu pengertian yang mendalam mengenai konsep fenomenologi. Ensains Journal, 2(1), 19-24. https://doi.org/10.31848/ensains.v2i 1.148

Nuryanto, S., \& Izzaty, R. E. (2016). Peranan dongeng dalam pendidikan karakter pada Taman Kanak-kanak
Lazuardi Kamila di Surakarta. JPPM: Jurnal Pendidikan Dan Pemberdayaan Masyarakat, 3(1), 75-84. https://doi.org/10.21831/jppm.v3i1.8 063

Saparwati, M. (2012). Studi fenomenologi: Pengalaman kepala ruang dalam mengelola Ruang Rawat di RSUD Ambarawa (Tesis) [Universitas Indonesia, Depok]. http:/ / lib.ui.ac.id/file?file=digital $/ 20$ 302623-T30332-Studi fenomenologi.pdf

Spaulding, A. E. (2011). The art of storytelling telling truths through telling stories. California: The Scarecrow Press.

Sugiyono. (2016). Metode penelitian kuantitatif, kualitatif dan $R \quad \mathcal{E} D$. Bandung: Alfabeta.

Sukarno, Permanasari , A., \& Hamidah, I. (2016). The profile of science process skill (SPS) students of secondary high school: Case study in Jambi. International Journal of Scientific Engineering and Research (IJSER), 1(1), 79-83.

https://www.ijser.in/archives/v1i1/ MDExMzA5MTg=.pdf

Suzuki, W. A., Feliú-Mójer, M. I., Hasson, U., Yehuda, R., \& Zarate, J. M. (2018). Dialogues: The science and power of storytelling. JNeurosci: The Journal of Neuroscience, 38(44), 9468-9470. https:// doi.org/10.1523/JNEUROSCI. 1942-18.2018

Utomo, S. B. (2013). Mendongeng dalam perspektif pendidikan. Agastya: Jurnal Sejarah Dan Pembelajarannya, 3(1), 1-8. https://doi.org/10.25273/ajsp.v3i01.9 01 
